DOI: $10.17516 / 1997-1370-0689$

УДК 331.108.4:378.147:316.45=11

\title{
Training Economics Students for Innovative Activities
}

\author{
Aleksandr M. Aronova, Vladislav N. Rutskiy ${ }^{\mathrm{b}}$ \\ Kseniya A. Rutskayab and Ivan A. Drobyshev*b \\ ${ }^{a}$ Moscow City University \\ Moscow, Russian Federation \\ ${ }^{b}$ Siberian Federal University \\ Krasnoyarsk, Russian Federation
}

Received 14.02.2020, received in revised form 19.08.2020, accepted 10.11.2020

\begin{abstract}
An objective of this study is to develop some grounds for assessing and ensuring the readiness of economics students to participate in innovative projects. Having considered the principles of innovation economics and the reflexive-activity approach to the organization of educational process, we classified the tasks set before an economist in an innovative project and developed approaches to assess relevant competences. Using the model of assessing the individual progress of school students developed by the authors, we derived a level model of an economics student's readiness for innovative activities. We conducted a survey and collected data that manifest three types of college student attitudes towards innovative projects in different countries. The results allow us to make assumptions on the relevant differences in the national (European, Asian, Russian) higher education systems in terms of training economists for innovative activities, and to make several suggestions for professional programmes aimed to train economists to participate in innovative projects, and, in particular, in reflective-analytical gamification of education and the procedures to create a professional language for innovation teams.
\end{abstract}

Keywords: entrepreneurship, innovation, economics student, the level model of readiness for innovative activities, the model of individual progress.

Research area: economy.

Citation: Aronov, A.M., Rutskiy, V.N., Rutskaya, K.A., Drobyshev, I.A. (2020). Training economics students for innovative activities. J. Sib. Fed. Univ. Humanit. Soc. Sci., 13(11), 1853-1869. DOI: 10.17516/1997-1370-0689.

(C) Siberian Federal University. All rights reserved

* Corresponding author E-mail address: a.m.aronov@gmail.com; vrutskiy@sfu-kras.ru; kbazhenova@sfu-kras.ru; idrobyshev@sfu-kras.ru ORCID: 0000-0003-1020-590X (Rutskiy); 0000-0003-1989-553X (Rutskaya); 0000-0002-0251-3323 (Drobyshev) 


\section{Introduction}

Due to the rapidly changing needs of the current technological platform, the problem of professional training in economics and management is of great interest for economists and educationalists. One of the trends in the post-industrial economy is innovative entrepreneurship. Attention of business, government and researchers shifts from implementing single innovative products to developing innovative entrepreneurship as a specific form of deep division of labour in organizations, innovation systems and network innovation structures (Kovalevich \& Shchedrovitsky, 2016).

Let us address the OECD definition of innovation: "An innovation is an implementation of a new or significantly improved product (good or service), or process, a new marketing method, or a new organizational method in business practices, workplace organization or external relations" (Oslo Manual, 2018). Based on the novelty degree, OECD classifies innovations into three levels: a company level, a (sectoral or spatial) market level and a level of global economy. At the same time, innovative activity arises in the activities of "productive" entrepreneurs, who form value chains at all steps, from basic research to spreading innovation and meeting the demand for a product (Baumol, 1990). For the purposes of our research, it is significant to note that J. Schumpeter, the founder of studies of innovations in economics, considered an innovation to be more than an invention itself, but "....an implemented method of using it in systems of technological division of a labour" (Kovalevich \& Shchedrovitsky, 2016). Implementing “...a method of using..." (of an invention) and, more broadly, switching to a new division of labour relations evokes the importance of a task to form new anthropological and professional qualities necessary to ensure functioning of innovation systems.

Thereby, a higher education system faces a demand to train economic and managerial personnel capable of acting independently and responsibly in an existing or a new organization during transition from streamlined business processes to a new system of technological, organizational and managerial processes that an innovation consists of (according to the Schum- peter's definition). In this context, a demand for developing general professional competencies besides special entrepreneurial competences is discussed.

\section{Defining the objective \\ of studying professional training \\ of economics students for innovative activities}

In order to successfully implement an innovative project (especially a technology startup), readiness of the project participants to act in situations of high uncertainty, maximizing the efficiency and independence of actions, the creativity of proposed solutions and communicative competences, are crucial. This statement is based on a fairly obvious assumption that, besides research fellows and engineers, any technology requires specialists in economics and liberal arts for managing, ensuring logistics and sales, training prospective personnel (Aronov, 2017).

Is Russian higher education ready to shift from streamlined processes to innovations? Currently, there is a wide array of publications on topics of developing entrepreneurial competencies and special issues of economists' training (language, mathematics, communication, IT etc.). The economists' training is discussed from the perspective of searching for new teaching methods that would expand the communicative and operational skills of the students. Development of a professional training curriculum for the innovative economy has been discussed by few authors based on the analysis of existing professional, educational standards and employers' survey. A theoretical basis for the curriculum design is constituted by an idea that innovation is an activity associated with risk and creativity (Lytneva \& Parushina, 2016). Practitioners note that project-based learning and case method are effective for training economists, managers (Aleksenko et al., 2015) and entrepreneurs (Shirokova et al., 2015). At the same time, Russian entrepreneurial education faces a number of problems, such as discrepancy between the competences formulated in the curriculum and the market demand; poor teaching methods; lack of consistency in acquiring theoretical and practical entrepreneurial skills; unfriendly 
university environment (Pluzhnik et al., 2018). According to the Global University Entrepreneurial Spirit Students' Survey international project (GUESSS), high readiness for entrepreneurship among Russian students (27\% of Russian survey participants, in comparing to $21 \%$ participants of other nations) is followed by low involvement of students in entrepreneurial education (less than $45 \%$ of Russian participants). The largest proportion of respondents $(61 \%$ in Russia vs. 32\% abroad) consists of economics and law students (Shirokova et al., 2016).

No publications on the topic provide any analysis of methods and levels to look up to while stimulating activity of an economist in an innovative project. A concept of "innovative activity" implies that professional training requires educational space that allows acquiring a set of norms different from those needed to act in a situation of a streamlined business processes (Rutskiy, Tanenkova, 2017). The purpose of this article is to develop a level model of an economics students' readiness for innovative activities. To achieve this goal, we studied the readiness of economics students for innovations. We formulated methodological and practical grounds to perform an experiment while training economists to work in an innovative project, and conducted a survey aimed to identify the economics students' readiness for innovative activities in different socio-economic and cultural environments.

We believe that a programme for innovative economists' education should be based on the level model of the students' readiness for innovative activities. First of all, steps to implement an innovative project and an economist's professional tasks in these steps, as well as the level model of developing a culture-adequate method/manner of action, need to be defined. A separate article will be devoted to provide a methodological support for designing a curriculum based on a model of generalized educational results relevant to economics education.

\section{Substantiating the level model of economics students' readiness for innovative activities}

The stages of developing and implementing an innovative project include various pro- cesses: creating new knowledge in private and public research and educational institutions, transferring knowledge, forming new added value while producing goods and services (Baumol, 1990). These stages make up the following sequence:

1. Basic scientific research.

2. Applied research.

3. Experimental research and engineering.

4. Making a prototype: a product, a key device, an asset, ensuring an intellectual property.

5. Small-scale production of new products or a business model optimization (both adding new value and controlling business processes).

6. Capturing new markets (creating new markets or capturing existing ones). As a rule, it occurs in large-scale production of a developing or an established business.

7. Diffusion of innovations. Spreading of innovative products and ideas into related industries goes in a form of knowledge transfer.

With this list being put into the context of our study, we have a great interest in readiness for commercialization of new knowledge at the fourth and fifth stage. Resources of any project are always naturally limited, while the expected results and outcomes are highly uncertain. As far as these assumptions are taken into account, the entrepreneurial competences of economists and managers become extremely sought for altogether with the ability to raise and manage resources (primarily financial and labour), designe a business model, calculate business efficiency and optimize business processes in a highly volatile environment at start, at growth stage and upon completion of a venture investment (Pyzhev \& Rutskiy, 2018).

In process of key project production and management tasks solving, economists and managers acquire an ability to solve different types of subject-specific tasks, an ability to transform a way of problem solving, an ability to unleash one's creative and socio-psychological potential, developed through training and practical experience. Problem solving is not an individual, but a group activity, that requires a combination of "hard skills" (special profes- 
sional knowledge, skills and abilities) and "soft skills": erudition and outlook, rhetorics and literacy, etiquette and punctuality, creativity and originality, communication skills and management, giving presentations and conducting negotiations etc. (Dalibozhko et al., 2018).

\section{Developing the level model \\ of economics students' readiness \\ for innovative activities}

To determine the concept of innovative economists' training, it is necessary to point out the innovative entrepreneurial activity tasks related to the professions of an economist and manager (Pluzhnik et al., 2018). Our analysis of professional tasks suggests that the tasks of an economist remain invariable at each stage of a new knowledge commercialization (Bourgault \& Jaouad, 2014; Škrinjarić, 2016; Lytneva \& Parushina, 2016; Ivonina et al., 2017). Both making prototypes and launching a small-scale production involve analytical, project designing and implementation activities. The only changing aspect is a degree of uncertainty and complexity, that, along with the increasing difficulty of scaling up business processes during commercialization of an innovation, has to be overcome by one's own efforts.

In order to develop the model of economics students training for professional innovative activities, first of all, we consider an essence of economist's activities in an innovative project. According to the current publications, we mark out three types of professional tasks that an economist faces at the stage of new knowledge commercialization in innovative projects and start-up companies:

1. Analytics. Analysing and evaluating economic feasibility of a project business model, which implies making an effort to collect the necessary data (especially market, operational and financial data) and to evaluate a method of adding value of offered goods and services. Features of these analytical tasks are determined by complexity of business goals and data sources at each stage of the project.

2. Project designing tasks with elements of managerial tasks. Project design implies taking actions to develop a business model focused on increasing the speed and re- ducing the cost of engineering, production and marketing business processes. Designing may, for example, involve financial planning and investment raising: calculating production costs along with predicting business growth rates, i.e. planning revenues and expenditures, assessing investment needs, presenting the project to investors, etc. That also includes making a production plan for the project (including staff instructions), a marketing strategy and marketing plan, a supply management plan, a human resources management strategy and associated plans, all necessary documentation and correspondence etc.

3. Practical implementation tasks. These tasks include project implementation activities within the framework of the project division of labour and the business model. For example, actions may concern accounting and filling out various generalized reporting forms: analysing expenses incurred and income received, interpreting profits and prospects to use it, making and presenting financial reports, justifying the funding strategy etc. These actions may include sales and procurement; communicating with customers and suppliers for the project; planning, motivating and controlling the project staff; communicating with parties involved, developing the overall project strategy and manners of effective actions for the participants.

At the same time, an innovative economist's tasks naturally become more complex when switching from solving typical production problems to non-standard ones. We assume that typical production tasks are those requiring "blueprint actions" to be accomplished, i.e. based on a precedent from someone else's experience, from a university course or from practice of an existing enterprise or a project. Non-typical tasks can be presented as a set of standard ones; accomplishing this type of tasks requires exclusive solutions. For example, designing and implementing a fast and cheap way to perform a key business transaction, establishing a communication method with a key target consumer group, developing a successful negotiation model with venture capital investors etc.

Let's move on to a description of the proposed level model of students' readiness for 
innovative activities. We refer to the level model of developing thinking and understanding processes during acquisition of object-aimed manner of action (the individual progress model of a school student) (Aronov et al., 2006; Bazhenova \& Znamenskaia, 2017). At present, the level model of school students' individual progress in educational activities consists of three levels: reproductive, reflexive, and resource.

The first (reproductive) level is the level of acquiring an external structure of an object-aimed action. The skill of accomplishing typical tasks by reproducing an algorithm (rule-based problem solving) is developed. To perform an action at this level, it is enough to apply some known samples, to complete some professional try-outs supervised by a teacher/ mentor. Since the model was developed to assess an individual student's progress rather than to aid designing a curriculum, it is important to us to interpret understanding as an ability to regard someone else's action as a significant one, and to interpret thinking as an ability to mark out operational composition in someone else's action.

The second (reflexive) level implies establishing relevant connections while developing a method to solve a problem full of additional irrelevant ("noise-making") details, on the basis a known method supplemented by additional analysis. This type of action is called a reflexive action associated with an act of understanding, what a topic of a problem situation $i s$. The result of an action at this level is a generalized problem-solving model that requires marking out a significant relationship between topics, details, circumstances etc. At this level, it is important to interpret understanding as marking out and highlighting relevant relationships, and to interpret thinking as developing a generalized manner of solving a whole class of problems.

The third (resource) level describes an action in the functional-semantic context of problem solving, which requires modifying an existing method/manner. It may be explained as "...acting in reliance on the functional-semantic presentation of a problem as a system of mutually agreeing elements: objective, con- ditions, means". At this level, it is important to interpret understanding as transferring a generalized method/manner of action to another sphere or domain, and to interpret thinking as a self-sustained task making in the new topic or sphere.

At present, the model described by the authors of this article is applicable to monitoring individual progress of school students acquiring item-specific methods/manners of action. When describing a student's model of readiness for innovative activities in their interaction with labour market, we highlight the two key factors that require refining the individual progress model in order to describe readiness of that kind.

Firstly, at university, acquiring a culture-adequate method/manner of action is related to acquiring a method/manner of solving real world-based educational tasks (in this study, these are analytical, project designing and practical implementation tasks of an economist in an innovative project) (Aronov \& Ermakov, 2015). Secondly, readiness for action in an innovative project manifests itself beyond the scope of action with a given item and implies personal initiative (which demonstrates a conscious attitude towards learning and setting individual tasks to transform a curriculum and to carry out professional activities). Accordingly, in addition to a competence model of educational process outcomes, which is popular in today's education theory, there is a need for an additional characteristic related to learning-and-professional and professional-and-learning reflection, where a dynamics level of an initiative is taken into consideration. The first type of reflection views students as persons being educated (object of education). The second type views students as persons responsible for their own education, able to independently organize their educational process and reflect upon their activities in solving professional problems.

The model of students' readiness for innovative activities includes categories of skill, knowledge, ability and competence. In this context, skill means assimilating a way of transforming input data (materials) to develop a product with specified characteristics. 
Knowledge is understood as focusing on and making a mental note of ways and means used to perform the input data transformation. Ability implies acquiring generalized methods and means for working with quite arbitrary materials or data and is regarded as a characteristic of readiness to perform transforming of the said materials or data. By competence we understand functional application of knowledge, means and methods, that manifests itself when a person acts in a difficult situation; in other words, it is an ability to compile some techniques to solve a problem in a challenging situation (Aronov \& Ermakov, 2015; Bazhenova \& Znamenskaia, 2017). The contexts, where professional competences of graduates are manifested, are related to their generalized attitudes to activities (Golub et al., 2008). In our opinion, professional competences can be understood as competence levels of a professional in a business project. Then the reproductive competence level (a threshold level in terms of assessing a professional's readiness) is an ability to act in a standard situation of a streamlined business project. It can be referred to the context of "...labour relations as organizing duties of an employee (but not direct interaction with the object of labour, in which professional competence manifests itself first of all)". The reflexive competence level (or simply "competence") manifests itself in the context of "...promoting oneself as an employee in the field of employment or self-employment (professional self-determination)". The functional-semantic (resource) competence manifests itself in the "vertical and horizontal interaction in a team" context.

To describe activities of an economist in an innovative project, the key professional competencies in the form of general and specific competencies need to be defined, as demonstrated by (Aronov \& Ermakov, 2015). General professional competences include understanding of technology and characteristics of a final product or service, an ability to use different technological solutions to achieve a result corresponding to certain standards. Specific professional competences include knowledge of properties and characteristics of fixed assets, specific equipment, raw materials, and data, an ability to quickly and effectively use these properties and features to operate. We assume that students are ready for innovative activities when they demonstrate key professional (both general and specific) competences developed at a certain level.

Developing the ability for professional-and-learning reflection implies active modelling of professional activity in the educational process. Development of learning-and-professional reflection is supported by a teacher functioning as a tutor. Active modelling requires an additional position of a supervisor. Of course, a mentor is required as well to ensure readiness to transit from the educational process to the production process.

In order to attain the first (reproductive) competence level, a try-out in setting personal goals and objectives of the educational process (a claim for a level of educational results to be achieved) becomes a subject of learning-and-professional reflection. Students interpret grade criteria, bring them into correlation with the typical study tasks (which requires passing a test in any form) and with their personal goals.

Reaching the second (reflexive) level requires that the main subject of learning-and-professional reflection is changed to a steady interest to assess one's own abilities, to summarize their experience of solving educational and professional tasks. Students start to work on their own initiative in practical training (regarding production process) and make independent try-outs to gain experience of obtaining their own results.

Reaching the third (resource) level implies that the main subject of learning-and-professional reflection is changed to identifying conditions needed to acquire an integrative competence to manage their own resources, capabilities and risks in learning-and-professional activities.

A criterion to attain a next level is a student's ability to set personal goals aligned to their results in the educational process, resources, and tasks of the production process.

Thus, introducing the concept of learning-and-professional reflection to teaching 
and learning at a higher educational institution, and the concept of professional-and-learning reflection to professional production management training, ensures improving readiness for innovative activities from one level to another, as well as the ability to take different positions in the academic and production process.

Table 1 sums up the key characteristics of each model level.

\section{A sociological study \\ of economics students' readiness \\ for innovative activities, with respect \\ to various socioeconomic \\ and cultural backgrounds}

To put the level model to a test and to determine the readiness of real economics students for participating in an innovative project, we developed a questionnaire. The respondents were

Table 1. The level model of economics students' readiness for innovative activities

\begin{tabular}{|c|c|c|c|}
\hline & $\begin{array}{c}\text { Level } 1 \\
\text { Reproductive }\end{array}$ & $\begin{array}{c}\text { Level } 2 \\
\text { Reflexive }\end{array}$ & $\begin{array}{c}\text { Level } 3 \\
\text { Resource }\end{array}$ \\
\hline 1 & 2 & 3 & 4 \\
\hline Skills & $\begin{array}{l}\text { One performs a task that } \\
\text { only requires identifying } \\
\text { its type and implement- } \\
\text { ing a given formalized } \\
\text { pattern (algorithm, rule) } \\
\text { for the action, relying on } \\
\text { obvious signs. } \\
\text { One follows instructions } \\
\text { on performing typical } \\
\text { production tasks when } \\
\text { reproducing an action, } \\
\text { following an example, is } \\
\text { needed }\end{array}$ & $\begin{array}{l}\text { One solves problems that } \\
\text { require taking actions } \\
\text { based not on the exter- } \\
\text { nal characteristics of the } \\
\text { problem, but on relevant } \\
\text { relations/connections } \\
\text { (between concepts, phe- } \\
\text { nomena, events, observa- } \\
\text { tions, data), that require } \\
\text { abstracting from random } \\
\text { data. } \\
\text { One makes adjustments } \\
\text { to a business model if } \\
\text { an emerging production } \\
\text { problem has a material } \\
\text { impact on business pro- } \\
\text { cesses. One implements } \\
\text { the solved production } \\
\text { problem in the business } \\
\text { model, overcoming ob- } \\
\text { stacles and excessive ir- } \\
\text { relevant data }\end{array}$ & $\begin{array}{l}\text { One performs tasks that require imple- } \\
\text { menting a learned method of acting into } \\
\text { a system of other available intellectual } \\
\text { resources, where it is needed as means } \\
\text { to transform materials (data) for another } \\
\text { subject. } \\
\text { One has applied knowledge of a method } \\
\text { (when needed to modify the method or } \\
\text { conditions to use it). } \\
\text { One transforms professional production } \\
\text { tasks into a business model, overcoming } \\
\text { an absence of essential data and deter- } \\
\text { mining conditions for acting. } \\
\text { One completes the problem situation in a } \\
\text { way, that makes a well-known method of } \\
\text { action applicable, or transforms the situ- } \\
\text { ation, so it becomes applicable }\end{array}$ \\
\hline Knowledge & $\begin{array}{l}\text { One knows typical } \\
\text { (standard) procedures, } \\
\text { techniques, methods, in- } \\
\text { structions to identify and } \\
\text { perform typical produc- } \\
\text { tion tasks. } \\
\text { One is familiar with ex- } \\
\text { amples of actions }\end{array}$ & $\begin{array}{l}\text { One knows means (in- } \\
\text { structions, techniques), } \\
\text { allowing to perform a set } \\
\text { of professional tasks. } \\
\text { One has knowledge to } \\
\text { identify and model a rele- } \\
\text { vant relation/connection. } \\
\text { One knows means for } \\
\text { making connections be- } \\
\text { tween data }\end{array}$ & $\begin{array}{l}\text { One knows principles, models, tech- } \\
\text { niques allowing to solve professional } \\
\text { problems, that require searching addi- } \\
\text { tional information and transforming a } \\
\text { problem to a task: } \\
\text { 1. To mark out the problem in a profes- } \\
\text { sional situation. } \\
\text { 2. To set the task based on the situation } \\
\text { analysis and to identify a relevant rela- } \\
\text { tion/connection. } \\
\text { 3. Based on the relevant relation/con- } \\
\text { nection, to develop a method of acting. } \\
\text { If necessary, to use it as intermediary } \\
\text { means to develop a more complex meth- } \\
\text { od of acting }\end{array}$ \\
\hline
\end{tabular}


Continuation Table 1

\begin{tabular}{|c|c|c|c|}
\hline 1 & 2 & 3 & 4 \\
\hline Abilities & $\begin{array}{l}\text { One has a positive atti- } \\
\text { tude towards knowing a } \\
\text { method of acting and re- } \\
\text { producing it via multiple } \\
\text { repetitions. One is ready } \\
\text { to carry out a try-out of } \\
\text { the method, identify a } \\
\text { relation/connection be- } \\
\text { tween conditions and the } \\
\text { method implementation }\end{array}$ & $\begin{array}{l}\text { One has knowledge of a } \\
\text { method in a generalized } \\
\text { form. One is able to de- } \\
\text { velop the method indi- } \\
\text { vidually to solve a profes- } \\
\text { sional problem on a basis } \\
\text { of conditions analysis } \\
\text { and a known method, and } \\
\text { to develop a generalized } \\
\text { model of this task }\end{array}$ & $\begin{array}{l}\text { For every new situation, one is capable of } \\
\text { developing a method of acting similar to } \\
\text { the previous situation: } \\
\text { 1. Developing a model for the method of } \\
\text { acting in a known situation. } \\
\text { 2. Using the model outside the situation } \\
\text { (for types of tasks different from the one } \\
\text { this algorithm was developed for) }\end{array}$ \\
\hline Competence & $\begin{array}{l}\text { One acts in a typical } \\
\text { (standard) situation of } \\
\text { a streamlined business } \\
\text { project, works with real } \\
\text { risks under guidance of } \\
\text { a mentor, using given } \\
\text { performance criteria, } \\
\text { while remaining within } \\
\text { a framework of a division } \\
\text { of labour system (thresh- } \\
\text { old competence) }\end{array}$ & $\begin{array}{l}\text { One performs a reflexive } \\
\text { action associated with } \\
\text { an act of understanding } \\
\text { a "subject/essence" of } \\
\text { a task. One sets goals } \\
\text { higher than one's official } \\
\text { duties in the division of } \\
\text { labour demand (reflexive } \\
\text { competence) }\end{array}$ & $\begin{array}{l}\text { One acts relies upon functional-seman- } \\
\text { tic representation of a task as a system } \\
\text { of mutually agreed elements: objective, } \\
\text { conditions, means. } \\
\text { In an innovative project, one is capable of } \\
\text { acting in accordance with technical lim- } \\
\text { itations, carrying out production tasks } \\
\text { and evaluating effectiveness of possible } \\
\text { solutions (combining creativity and stan- } \\
\text { dard rules) }\end{array}$ \\
\hline $\begin{array}{l}\text { Learn- } \\
\text { ing-and- } \\
\text { professional } \\
\text { Reflection / } \\
\text { Profession- } \\
\text { al-and-learn- } \\
\text { ing Re- } \\
\text { flection }\end{array}$ & $\begin{array}{l}\text { One sets personal goals } \\
\text { and objectives, choos- } \\
\text { es a level of achiev- } \\
\text { ing educational and } \\
\text { professional results }\end{array}$ & $\begin{array}{l}\text { One assesses one's own } \\
\text { capabilities, sums up an } \\
\text { experience of obtain- } \\
\text { ing one's own results } \\
\text { in solving educational } \\
\text { and professional tasks }\end{array}$ & $\begin{array}{l}\text { One acquires an integrative com- } \\
\text { petence of managing one's own } \\
\text { resources, capabilities and risks in } \\
\text { learning-and-professional activities }\end{array}$ \\
\hline
\end{tabular}

economics students from three countries, three socioeconomic and cultural environments. The respondents from various universities of Russia and China were participants of the International Summer School named "Contemporary Problems of Economics and Practice", held at the Siberian Federal University (Krasnoyarsk, Russia) in 2017 and 2018. Respondents from Europe were students of a short lecture course at the University of Granada (Spain) in 2017. At the Summer School, during an "Entrepreneurship, Development, Innovation" class, Russian and international students became acquainted with theoretical basis of the course, discussed actual experience of innovative activities with experts, and took part in designing and presenting an innovative project. A short-term interactive lecture course "Regional Innovation
Systems" for bachelor students majoring in Economics at the University of Granada was aimed at discussing applied results of the international project "Technology transfer in post-socialist economies - the case of Ukraine and Russia in comparison with East Germany and Poland". Our survey was conducted before the course focused on innovative activities and an economist's tasks in an innovative project.

The questionnaire consisted of four parts. The first part was intended to collect data on general ideas of the respondents about innovative projects. The survey participants were offered to list the innovative projects they were familiar with, to list the key characteristics of an innovative project, to tell about an experience of participating in such projects or meeting with innovators in person. 
The second part of the questionnaire recorded the students' knowledge of an economist's innovative tasks. The third part allowed us to gather data on the students' attitude towards educational process, i.e. to assess a possibility of presenting the educational process at a university as implementation of an innovative project. While composing the questions, we assumed that "innovativeness" could manifest itself as inventing a way of learning and building a productive relationship with lecturers, and making it a common practice. We assumed that enlarging the third part of the questionnaire and including case studies in it would make it possible to determine the level of students' readiness for innovative activities.

The fourth part of the questionnaire was dedicated to observing ways of student life that allowed to develop competences of an innovative project's economist. 144 students took part in the survey: 40 students from Russia, 68 students from China, 36 students from Spain.

In the first part of the questionnaire, the following data were collected. Of all the respondents, only one student has ever had a conversation with an innovator. The rest only listed innovative (in their opinions) projects that, however, were quite diverse. Asked to list innovations, students cited individual businesses (e.g. the Alipay payment platform), individual technologies (like NFC chips in smartphones) and market products (Tesla Electric Cars).

In order to explore the students' ideas about innovations, they were offered some characteristics of innovative activities (Table
2). Only the last characteristic ("systematic profit, above the average market level") was not the one that determined an innovative activity (since profit also comes from other factors, e.g. a monopolistic position of a company). According to the obtained results, the students intuitively identified relevant characteristics of an innovative process. However, they did not view "discovering new market niches" as a relevant marketing innovation.

The responses of the Russian students were mostly associated with technological innovations rather than organizational ones. At the same time, the Chinese and Spanish students were aware that innovation was possible at different stages of production and product introduction.

The second part of the questionnaire was expected to determine a place of the economist's tasks in a streamlined business and in innovative business. Generally, the Russian-speaking students' responses suggested that they did not distinguish specific tasks of an economist in an innovative project; all of these tasks were marked important for both types of business. Chinese and Spanish students, on the contrary, thought of the tasks related to market evaluation of a business model (i.e. ways to form the added value chain of a product/service/work on the market) as the main tasks of an economist in an innovative project. For Chinese students, organizing interaction and communication between participants in an innovative project was also an important task. Spanish students highlighted the same task, and also added tasks of

Table 2. Characteristics of innovations*

\begin{tabular}{|l|c|c|c|}
\hline \multirow{2}{*}{ Characteristics of innovations } & \multicolumn{3}{c|}{ Observed frequency, \% } \\
\cline { 2 - 4 } & Russian students & Chinese students & Spanish students \\
\hline Developing new products & 90 & 70.6 & 88.9 \\
\hline Developing new technologies & 100 & 58.8 & 77.8 \\
\hline Finding and using new sources of raw materials & 40 & 47.1 & 33.3 \\
\hline Organizing new production methods & 60 & 52.9 & 44.4 \\
\hline Discovering new market niches & 30 & 29.4 & 33.3 \\
\hline $\begin{array}{l}\text { Generating systematic profit above an average mar- } \\
\text { ket level }\end{array}$ & 10 & 11.8 & 11.1 \\
\hline
\end{tabular}

${ }^{*}$ Compiled on a basis of surveys conducted by the authors of the paper. 
analysing markets and interpreting incomes, expenses and prospects for profit usage.

So, Russian students could not mark out any specific professional tasks of an economist in an innovative project: they evaluated all the tasks as relevant with no regard to the business specificity. Interpreting the survey results, as far as educational activities are concerned, suggests that the students experienced difficulties in self-determination and choosing professional tasks, that might be challenging to solve. High frequency of the second option drives us to the assumption that Russian students tended to experience difficulties in cooperating: they were ready to accept full responsibility for the process, and preferred not to delegate any of the professional tasks to colleagues. Consequently, Russian economics education is not aimed at preparing economists to participate in an innovative project and is more general or universal in essence.
Due to crucial importance of communicative tasks in real innovative projects for an innovative economist, we added to the questionnaire a special block of questions on the said communicative tasks. The results confirmed the assumption that Russian students were less (than Chinese or Spanish students) ready for working in a team and delegating their functions (Table 3-5).

The next question allowed us to describe the students' representations of an economist's innovative behaviour in a company. The Chinese students identified developing action plans for a company, when introducing a new product to a market, as a relevant indicator of an economist's innovative behaviour $(82.4 \%$ of the responses). In addition to that opinion, the Russian students marked the indicator "Setting more ambitious goals than required by the company. Exploring and unleashing one's potential to achieve them" as equally relevant:

Table 3. Differentiating the tasks of an economist in an innovative project in comparison with a streamlined business*

\begin{tabular}{|c|c|c|c|c|c|c|c|c|c|c|c|c|}
\hline \multirow{3}{*}{ Professional tasks } & \multicolumn{12}{|c|}{ Observed frequency, $\%$} \\
\hline & \multicolumn{3}{|c|}{$\begin{array}{l}\text { Not an econ- } \\
\text { omist's task }\end{array}$} & \multicolumn{3}{|c|}{$\begin{array}{l}\text { Relevant for } \\
\text { a streamlined } \\
\text { business }\end{array}$} & \multicolumn{3}{|c|}{$\begin{array}{l}\text { Relevant } \\
\text { regardless of a } \\
\text { business type }\end{array}$} & \multicolumn{3}{|c|}{$\begin{array}{l}\text { A task of an } \\
\text { innovative } \\
\text { economist }\end{array}$} \\
\hline & Rus & Chi & Spa & Rus & Chi & Spa & Rus & Chi & Spa & Rus & Chi & Spa \\
\hline $\begin{array}{l}\text { Using standard data collection meth- } \\
\text { ods }\end{array}$ & 0 & 17.6 & 0 & 30 & 35.3 & 44.4 & 70 & 47.1 & 55.6 & 0 & 0 & 0 \\
\hline $\begin{array}{l}\text { Evaluating a business model (ways } \\
\text { to form an added value chain of } \\
\text { goods, services, works) }\end{array}$ & 0 & 0 & 0 & 0 & 5.9 & 11.1 & 90 & 35.3 & 11.1 & 10 & 58.8 & 77.8 \\
\hline $\begin{array}{l}\text { Analysing market opportunities and } \\
\text { market penetration }\end{array}$ & 0 & 0 & 0 & 20 & 17.6 & 0 & 50 & 58.8 & 50 & 30 & 23.5 & 50 \\
\hline $\begin{array}{l}\text { Developing a production plan for a } \\
\text { project }\end{array}$ & 0 & 0 & 0 & 30 & 18.8 & 22.2 & 60 & 50 & 33.3 & 10 & 31.3 & 44.4 \\
\hline Preparing accounting reports & 10 & 23.5 & 0 & 20 & 35.3 & 37.5 & 60 & 41.2 & 50 & 10 & 0 & 12.5 \\
\hline $\begin{array}{l}\text { Interpreting data on expenses and } \\
\text { incomes, prospects for profit usage }\end{array}$ & 0 & 11.8 & 0 & 10 & 29.4 & 12.5 & 70 & 47.1 & 37.5 & 20 & 11.8 & 50 \\
\hline $\begin{array}{l}\text { Organizing sales and customer com- } \\
\text { munication }\end{array}$ & 0 & 23.5 & 22.2 & 20 & 17.6 & 22.2 & 70 & 47.1 & 44.4 & 10 & 11.8 & 11.1 \\
\hline $\begin{array}{l}\text { Organizing procurement and com- } \\
\text { municating with suppliers }\end{array}$ & 0 & 0 & 25 & 30 & 23.5 & 37.5 & 60 & 70.6 & 37.5 & 10 & 5.9 & 0 \\
\hline $\begin{array}{l}\text { Organizing interaction and commu- } \\
\text { nication between participants of an } \\
\text { innovative project }\end{array}$ & 0 & 5.9 & 0 & 10 & 23.5 & 22.2 & 80 & 23.5 & 66.7 & 10 & 47.1 & 11.1 \\
\hline
\end{tabular}

* Compiled on the basis of surveys conducted by the authors of the paper. 
Table 4. Significance of organizing interaction and communication between participants of an innovative project compared to a streamlined business - as an economist's task ${ }^{*}$

\begin{tabular}{|c|c|c|c|c|c|c|c|c|c|c|c|c|}
\hline \multirow{3}{*}{ Professional tasks } & \multicolumn{12}{|c|}{ Observed frequency, $\%$} \\
\hline & \multicolumn{3}{|c|}{$\begin{array}{l}\text { Not an econ- } \\
\text { omist's task }\end{array}$} & \multicolumn{3}{|c|}{$\begin{array}{l}\text { Relevant for } \\
\text { a streamlined } \\
\text { business }\end{array}$} & \multicolumn{3}{|c|}{$\begin{array}{l}\text { Relevant } \\
\text { regardless of a } \\
\text { business type }\end{array}$} & \multicolumn{3}{|c|}{$\begin{array}{l}\text { The task of } \\
\text { an innovative } \\
\text { economist }\end{array}$} \\
\hline & Rus & Chi & Spa & Rus & Chi & Spa & Rus & Chi & Spa & Rus & Chi & Spa \\
\hline $\begin{array}{l}\text { Developing a strategy, demonstrat- } \\
\text { ing examples of effective actions to } \\
\text { participants }\end{array}$ & 0 & 5.9 & 0 & 10 & 23.5 & 0 & 60 & 35.3 & 55.6 & 30 & 35.3 & 44.4 \\
\hline $\begin{array}{l}\text { Organizing a project team's work in } \\
\text { accordance with the project plan }\end{array}$ & 0 & 11.8 & 0 & 30 & 17.6 & 22.2 & 60 & 41.2 & 44.4 & 10 & 29.4 & 33.3 \\
\hline $\begin{array}{l}\text { Inspiring project participants for ef- } \\
\text { fective actions, providing incentives } \\
\text { for effective work }\end{array}$ & 10 & 17.6 & 0 & 10 & 23.5 & 22.2 & 70 & 23.5 & 33.3 & 10 & 35.3 & 44.4 \\
\hline $\begin{array}{l}\text { Ensuring control over accomplish- } \\
\text { ing the assigned tasks }\end{array}$ & 10 & 23.5 & 0 & 10 & 35.3 & 22.2 & 50 & 35.3 & 22.2 & 30 & 5.9 & 55.6 \\
\hline $\begin{array}{l}\text { Providing training opportunities, } \\
\text { mentor assistance, advanced train- } \\
\text { ing }\end{array}$ & 20 & 17.6 & 0 & 20 & 23.5 & 11.1 & 50 & 35.3 & 44.4 & 10 & 23.5 & 44.4 \\
\hline
\end{tabular}

* Compiled on the basis of surveys conducted by the authors of the paper.

$60 \%$ of the respondents chose both options. The responses of the Spanish students were equally distributed, but the opinion on importance of developing a strategy in the situation of introducing a new product prevails $(66.7 \%$ of the responses).

It should be noted that according to experts from the business environment, who advised us on the questionnaire, working with real risks in a streamlined business under the guidance of a mentor is innovative behaviour, since it opens new opportunities for both marketing and production. The distribution of this choice was as follows: $10 \%$ of the Russian students, $11.8 \%$ of the Chinese respondents and $33.3 \%$ of the Spanish students.

In order to adequately interpret the students' responses, it is crucial to consider the specificity of corporate policies in different countries. If it supports an economist's participation in developing a plan of actions, then the students' assessment of this characteristic's significance describes the real situation.

The next set of questions was aimed at identifying students' attitudes towards the educational process as a model of an innovative process. The first of them allowed us to inter- pret whether the students set goals for their educational process. The results indicated that all the respondents from Russia declared that goal-setting for their learning process at school or college/university was an actual practice, $76.5 \%$ of the Chinese students and $75 \%$ of students from Spain did the same.

The respondents were asked about a student's possible behaviour towards the educational process: "If you were offered to become innovative in your educational process, then what would be your actions? Choose one option."

For economics students, teaching was not their professional major; therefore, inventing new effective ways of learning was an innovative task for them. The option that depicts a student's innovative behaviour, correlates with the basic stages of a start-up project: it displays the attitude towards a student's innovative behaviour, associated with inventing a method, testing it and spreading it among a group of students.

The first type of response (getting a higher score in one or more classes), means only an individual student's claim and is determined by the requirements set by the teacher. The option: "Your style of studies was more of "drifting 
Table 5. Students' attitudes towards educational process*

\begin{tabular}{|c|c|c|c|}
\hline \multirow[b]{2}{*}{ Alternative attitudes to the educational process } & \multicolumn{3}{|c|}{ Observed frequency, $\%$} \\
\hline & $\begin{array}{c}\text { Students } \\
\text { from Russia }\end{array}$ & $\begin{array}{l}\text { Students } \\
\text { from China }\end{array}$ & $\begin{array}{l}\text { Students } \\
\text { from Spain }\end{array}$ \\
\hline Getting a higher score in one or more classes & 28.6 & 0 & 0 \\
\hline $\begin{array}{l}\text { Coming up with a new effective way of learning (algorithm for } \\
\text { acquiring knowledge, skills; forms and means of communicat- } \\
\text { ing with a teacher; a method to overcome obstacles in learning). } \\
\text { Predicting the consequences of using the method. Applying an } \\
\text { effective way. Understanding, why the result is as it is. Offering } \\
\text { the method to classmates (optionally) }\end{array}$ & 57.1 & 92.9 & 66.7 \\
\hline $\begin{array}{l}\text { Your style of studies was more of "drifting with a flow". Now you } \\
\text { decided to set a goal: "To get the highest marks!". You diligently } \\
\text { do all the tasks the teacher gives you. At the exam, you get a } \\
\text { mark below the desired one. You are very upset about this }\end{array}$ & 14.3 & 7.1 & 33.3 \\
\hline
\end{tabular}

* Compiled on the basis of surveys conducted by the authors of the paper.

with a flow"..." is similar. The behaviour type "You diligently do all the tasks..." was not new for their educational experience; moreover, the following outcome of the situation in the form of emotional experience suggested that a method of achieving the desired result was not found.

The responses were distributed as follows. The Chinese students $(92.9 \%$ of the responses) were more oriented towards inventing effective ways of learning and distributing the knowledge, while the Russians $(57.1 \%$ of the responses) were less focused on learning. For the Spanish students, this option was the most significant (66.7\% compared to other options). Notably, only the Russian students chose "Getting a higher score..." as an innovative student's behaviour. We assume that these survey results indicate that students got confused with distinguishing innovative behaviour (inventing a "method" and its dissemination) and adapting to existing requirements. In addition, the results provide grounds to discuss the emotional attitude to a failure: the Russian and Chinese students were more tolerant to the situations of "injustice", while the Spaniards were hurt by this situation $(33.3 \%$ of the students chose the third option).

The final block of questions was aimed at exploring the students' ideas about an economist's professional tasks in an innovative project. Students identified practice in an "in- novative" enterprise, familiarizing with biographies of famous economists, mentoring by a business coach, classes at a higher educational institution as ways of learning. The diverse and unsystematic responses imply that there is no general systematic training for innovative activities in any country, which corresponds to the previously reported results of the GUESS project (Shirokova et al., 2016). Students can develop competence in an economist's integral tasks in an innovative project only by their own student initiative.

Thus, the results of the survey confirm a fact that organizing the economics students' training in participation in innovative projects requires developing a specialized academic curriculum. Readiness to participate in innovative projects means that students have an ability to engage in processes of improving and changing production, know how to evaluate and analyse benefits of technological processes, adapt to a real situation, know how to get necessary additional training, use innovations and change technologies. Ensuring this readiness imposes special requirements for actions of faculty and employers. Based on the results of the study, we suggest several conditions to be considered when developing the academic curriculum with innovative entrepreneurship in mind.

Firstly, the framework of reflexive-activity approach allows us to identify different types 
of students' results: learning, educational (in the specific sense) and qualification results (see Table 6) (Aronov, 2015; Bazhenova, 2014). The level model of students' readiness for innovative activities provides grounds to specify a principle of complicating tasks of an innovative economist in accordance with a type of results. The tasks will be changing from typical, i.e. performing actions, based on someone else's experience translated during university training or practice at an existing enterprise, to non-typical tasks: finding exclusive solutions; for example, designing and implementing a quick and cheap way to perform a key business operation, finding a way to communicate with a key target audience of consumers, developing a successful model of negotiations with venture capital investors etc. At the same time, a normative, recommendatory version of the level model of training students for innovative activities in Russia should be developed with restrictions and actions of relevant legislative bodies taken into account (see Table 6).

Furthermore, the results imply a need for varying degree of integration between employers and the educational institution. A goal of integration is to ensure not just access of students to modern production, but (more important- ly) relevant conditions to develop professional-and-learning reflection. At the same time, a task of a university is to ensure availability of specially designed tasks and "meta-courses", i.e. courses aimed at improving the conditions to develop learning-and-professional reflection (Aronov, Bazhenova, 2015). These courses allow a teacher to control the development process. When designing a process aimed at obtaining educational and qualification results, the following requirements for employers should be considered:

- being included in academic curriculum development;

- providing students with mentors and allowing trainees to solve real production problems with possible risks during internships;

- fully participating in final students' qualification evaluation procedures;

- providing real job offers after final students' qualification evaluation procedures followed by employment.

At the same time, students, studying under this type of academic curriculum organization, move from solving formalized (codified) cases, based on other people's experience, to developing their own non-formalized cases (they make a professional "portfolio" evaluated by employ-

Table 6. Guidelines to implement practice-oriented training based on a reflexive-activity approach in Russia

\begin{tabular}{|c|c|c|c|}
\hline Result Types & Features & Legislative Base & $\begin{array}{c}\text { Where, What and by } \\
\text { Whom is Evaluated? }\end{array}$ \\
\hline Learning outcomes & $\begin{array}{c}\text { Mastering stan- } \\
\text { dard operations }\end{array}$ & $\begin{array}{c}\text { GES (educational standards), the legisla- } \\
\text { tive body responsible: Ministry of Educa- } \\
\text { tion and Science of the Russian Federation }\end{array}$ & $\begin{array}{c}\text { Educational results } \\
\text { are evaluated } \\
\text { according to the } \\
\text { GES in a college/ } \\
\text { university }\end{array}$ \\
\hline Educational results & $\begin{array}{c}\text { Working with real } \\
\text { risks under guid- } \\
\text { ance of a mentor. } \\
\text { Achieving one's } \\
\text { own result }\end{array}$ & $\begin{array}{c}\text { Professional standard (requirements } \\
\text { for implementation of labour ac- } \\
\text { tions), the legislative body responsible: } \\
\text { Ministry of Labour and Social Pro- } \\
\text { tection of the Russian Federation }\end{array}$ & $\begin{array}{c}\text { Educational results } \\
\text { are evaluated ac- } \\
\text { cording to compe- } \\
\text { tencies described } \\
\text { as a professional } \\
\text { standard, during } \\
\text { internship }\end{array}$ \\
\hline Final sudents' & $\begin{array}{c}\text { Developing an inte- } \\
\text { grative competence. } \\
\text { Being competent in } \\
\text { dealing with oppor- } \\
\text { tunities and risks }\end{array}$ & $\begin{array}{c}\text { Corporate standards (requirements for } \\
\text { professional competence and ethics), } \\
\text { the legislative body responsible: cor- } \\
\text { porations, professional associations }\end{array}$ & $\begin{array}{c}\text { An evaluated level } \\
\text { is determined by } \\
\text { an employer in a } \\
\text { professional field }\end{array}$ \\
\hline
\end{tabular}


ers). In terms of competences, they move from developing and implementing a business model based on non-standard techniques to deeper understanding and scaling up, reproducing the model in a different context, with other resource constraints.

\section{Conclusions}

The results of the study suggest significant differences in national systems of higher education in terms of training economics students for innovative activities. At the same time, as far as the survey data allow to hypothesize, students from Russia are significantly less prepared for innovative activities (in particular, for risky actions, teamwork, for professional self-determination and communications in a market environment), than representatives of the European and Eastern educational systems, despite the rather high (according to international polls) ambitions of Russian students to participate in innovative projects. In general, the survey results confirm the thesis prevalent in the economic literature, that the innovation system of Russia and the corresponding educational environment are still closer to the Soviet model of "technological push" rather than more market-oriented models of "market pull" and "triple helix", well-known in many developed and developing countries of Europe and Asia, which were partially covered by the scope of our study.

Obviously, the research is preliminary, and it needs significant expansion of empirical basis, and improvements in research methodology, like combining a survey aimed at educational environment and an analysis of corporate practices of implementing innovative projects. At the same time, developed elements of the level model of innovative activity training and proposed competence features of economics' students (in terms of their readiness for innovations) can serve as a basis for the development and implementation of a pilot program of level training and the corresponding changes of academic curricula in Russian universities.

The presented theoretical level model of students' readiness for innovative activities, adapted to the higher education peculiarities, provides grounds for planning new educational courses and building a multi-level developing education system. Professional tasks, that should be performed by economists and managers in innovative projects, allow us to choose companies, industries, types of business, where students focused on innovative activity should have practical training and internships.

\section{References}

Aleksenko, N.V., Burmistrova, N.A., Ilina, N.I., \& Karpov, V.V. (2015). Proektno-kontekstnoe obrazovanie v realizatsii mnogourovnevoi podgotovki ekonomistov [The practice of project-contextual education in the realization of multilevel mathematical training of economists]. In Finansy: teoriia i praktika [Finance: Theory and Practice], 5, 143-152.

Aronov, A.M. (2015). Podkhody, faktory i printsipy realizatsii praktiko-orientirovannoi podgotovki na osnove refleksivno-deiatel'nostnogo podkhoda [Approaches, factors and principles for practice-oriented training implementation on a basis of the reflexive-activity approach]. In Deiatel'nostnaia pedagogika $i$ pedagogicheskoe obrazovanie: Sbornik tezisov III Mezhdunarodnoi konferentsii “DPPO-2015” [Activity pedagogy and pedagogical education: Proceedings of the III International Conference. “DPPO 2015”]. Voronezh, 12-14.

Aronov, A.M. (2017). Idealy professionalizma i tret'ia promyshlennaia revoliutsiia [Ideals of professionalism and the third industrial revolution]. In Molodye professionaly Krasnoyarskogo kraia: Sbornik analiticheskikh, informatsionnykh materialov po itogam forsait-foruma "Molodye professionaly Krasnoiarskogo kraia" [Young professionals of the Krasnoyarsk krai: Proceedings of the foresight forum]. Krasnoyarsk, 8-16.

Aronov, A.M., Balandin, O.G., Znamenskaia, O.V. et al. (2006). Monitoring individual'nogo progressa uchebnykh deistvii shkol'nikov [Monitoring the individual progress of schoolchildren's learning activities]. Krasnoyarsk, KPD Printing Center, 2006, 132 p. 
Aronov, A.M., Bazhenova, K.A. (2015). Sovremennaia tekhnologiia formirovaniia deiatel'nostnogo otnosheniia k obrazovatel'nomu protsessu u studentov-bakalavrov [Modern technology of developing activity-focused attitude to academic process in students-bachelors of pedagogy]. In Izvestiia Iuzhnogo federal'nogo universiteta. Pedagogicheskie nauki [News of the Southern Federal University. Pedagogical sciences], 11, 37-44.

Aronov, A.M., Ermakov, V.S. (2015). Poriadok podgotovki metodicheskikh rekomendatsii po obnovleniiu obrazovatel'nykh programm na osnove standartov WorldSkills po kompetentsiiam [The procedure of preparing the guidelines for updating educational programs based on WorldSkills standards for competencies]. Krasnoyarsk: Center for Modern Vocational Education Technologies, 16 p.

Baumol, W.J. (1990). Entrepreneurship: Productive, Unproductive and Destructive. In Journal of Political Economy, 98 (5), 893-920.

Bazhenova K.A. (2014). Konstruirovanie obrazovatel'nykh situatsii dlia studentov-bakalavrov pedagogiki [The trial of educational situation design for students of undergraduate course of pedagogy]. In Vestnik Moskovskogo universiteta. Seriia 20: Pedagogicheskoe obrazovanie [Moscow University Bulletin. Series 20: Teacher Education], 3, 73-83.

Bazhenova, K.A, Znamenskaia, O.V. (2017). Teacher's beliefs as a factor of individual progress of pupil. In European proceedings of social \& behavioural sciences EpSBS. Kazan, 100-108.

Bourgault, M., Daoudi, J. (2014). Innovation projects conducted by distributed teams: the impact of key team characteristics on collaboration. In Journal of Innovation Economics \& Management, 1 (13), 37-72.

Dalibozhko, A.I., German, M.V., \& Krakovetskaia, I.V. (2018). Povyshenie konkurentosposobnosti vypusknikov universiteta na rynke truda: vozmozhnost' formirovaniia tverdykh i miagkikh navykov v mezhdunarodnoi programme Enactus [Increasing the competitiveness of university graduates in the labour market: the possibility of forming hard and soft skills in the international program Enactus], In Izvestia Dal'nevostochnogo federal'nogo universiteta. Ekonomika $i$ upravlenie [The bulletin of the Far Eastern federal university. Economics and management], 1, 57-74.

Golub, G.B., Kogan, E.Ia., Fishman, I.S. (2008). Otsenka urovnia sformirovannosti kliuchevykh professional'nykh kompetentnostei vypusknikov UNPO: podkhody i protsedury [Assessing level of key professional competencies development of UNPO graduates: approaches and procedures]. In Voprosy obrazivaniya [Educational Studies], 2, 161-185.

Ivonina, A.I., Chulanova, O.L., and Davletshina, Iu.M. (2017). Sovremennye napravleniia teoreticheskikh i metodicheskikh razrabotok v oblasti upravleniia: rol' soft $\mathrm{i}$ hard skills $\mathrm{v}$ professional'nom i kar'ernom razvitii sotrudnikov [Modern directions of theoretical and methodological developments in the field of management: the role of soft skills and hard skills in the professional and career development of employees]. In Naukovedenie [Science Studies], 9 (1), 1-18, availible at: http://naukovedenie.ru/vol9-1.php

Kovalevich, D.A., Schedrovitsky, P.G. (2016). Konveier innovatsii [Innovations Conveyor]. Available at: http://asi.ru/conveyor-of-innovations (accessed: 27 November 2017).

Lytneva, N.A., Parushina, N.V. (2016). Kompetentnostnyi podkhod v podgotovke professional'nykh ekonomistov dlia malogo predprinimatel'stva [Competence approach in training for professional economists for small businesses]. In Sovremennye problemy nauki i obrazovaniia [Modern problems of science and education], 6, available at: http://www.science-education.ru/ru/issue/view?id=143

Nezhnov, P.G., Forbov, S.F., Sokolova, O.V. (2018). Diagnostika uchebno-predmetnykh kompetentsii [Diagnostics of subject-specific competences]. Moscow, Nonprofit partnership "Authors' club", 112 p.

Oslo Manual 2018 (2018). Guidelines for Collecting, Reporting and Technological Innovation Activities. OECD, European Union, 258 p. DOI: 10.1787/9789264304604-en

Pluzhnik, I.L., Ilnitskaia, T.O., Lucci, F. (2018). Predprinimateliami rozhdayutsia ili stanoviatsia? Effektivnye akademicheskie modeli obucheniia predprinimatel'stvu studentov vuzov [Are entrepreneurs born or made? Effective academic models to foster entrepreneurial graduates]. In Obrazovanie I nauka [The Education and Science Journal], 20 (5), 56-78.

Pyzhev, I.S., Rutskiy, V.N. (2018). Stanovlenie proizvoditel'nogo innovatsionnogo predprinimatel'stva $\mathrm{v}$ usloviiah poriadka ogranichennogo dostupa na primere rossiiskikh resursnykh regionov [Formation of 
productive innovative entrepreneurship in conditions of limited access order on the example of Russian "resource-type" regions]. In Zhurnal institutsional'nykh issledovanii [Journal of Institutional Studies], 10 (1), 125-136. DOI: 10.17835/2076-6297.2018.10.1.125-136

Rutskiy, V.N., Tanenkova, E.N. (2017). Institutsional'nye problemy vysshego obrazovaniia kak sfery transfera znanii i tekhnologii v postsotsialisticheskikh regional'nykh innovatsionnykh sistemakh [Institutional problems of higher education as a sphere of transfer of knowledge and technologies in post-socialist regional innovative systems]. In Institutsional'naia transformatsiia ekonomiki: prostranstvo i vremia. Sbornik dokladov V Mezhdunarodnoi nauchnoi konferentsii: v 2-kh tomakh [Institutional transformation of the economy: space and time. Proceedings of the V International scientific conference: in 2 volumes]. Kemerovo, 200-204.

Shirokova, G.V., Bogatyreva, K.A., Beliaeva, T.K., Tsukanova, T.V., Laskovaia, A.K. (2016). Global university entrepreneurial spirit students' survey. National report. Russia 2016. Available at: http://www. guesssurvey.org/resources/nat_2016/GUESSS_Report_2016_Russia_e.pdf (accessed 23 November 2017).

Shirokova, G.V., Tsukanova, T.V., \& Bogatyreva, K.A. (2015). Universitetskaia sreda i predprinimatel'skaia aktivnost' studentov: rol' biznes-opyta i predprinimatel'skoi samoeffektivnosti [University environment and student entrepreneurship: the role of business experience and entrepreneurial self-efficacy]. In Voprosy obrazovaniia [Educational studies], 3, 171-207. DOI: 10.17323/1814-9545-2015-3-171-207

Škrinjarić, B. Key Competences in economics and business field: the employers' side of the story. In International journal of social, behavioural, educational, economic, business and industrial engineering, $10(10), 3054-3062$. 


\title{
Подготовка студентов экономического профиля к инновационной деятельности
}

\author{
А.М. Аронов ${ }^{a}$ В.Н. Руцкийб, \\ К.А. Руцкая ${ }^{6}$ И.А. Дробышев ${ }^{6}$ \\ а Московский городской педагогический университет \\ Российская Федерачия, Москва \\ ${ }^{6}$ Сибирский федеральньй университет \\ Российская Федераџия, Красноярск
}

\begin{abstract}
Аннотация. Цель настоящего исследования - определить условия обеспечения подготовленности студентов экономического профиля к участию в инновационных проектах. С учетом принципов инновационной экономики и рефлексивнодеятельностного подхода к организации образовательного процесса была проведена декомпозиция задач экономиста в инновационном проекте и выработаны подходы к оцениванию соответствующих компетенций. На базе существенных характеристик авторской модели индивидуального прогресса школьников была разработана уровневая модель подготовленности студента-экономиста к инновационной деятельности. На основе анкетирования выделены три типа отношения студентов из разных стран к участию в инновационных проектах. Полученные результаты позволяют выдвинуть предположения о существенных различиях ряда национальных систем высшего образования (европейской, азиатской, российской) в части подготовки экономистов к инновационной деятельности, а также сформировать ряд требований к программированию подготовки экономистов к участию в инновационных проектах, в частности, по разработке рефлексивно-аналитической геймификации образовательного процесса и процедурам создания профессионального языка инновационной команды.
\end{abstract}

Ключевые слова: предпринимательство, инновации, студенты экономического профиля, уровневая модель подготовленности к инновационной деятельности, модель индивидуального прогресса.

Научная специальность: 08.00.00 - экономические науки. 